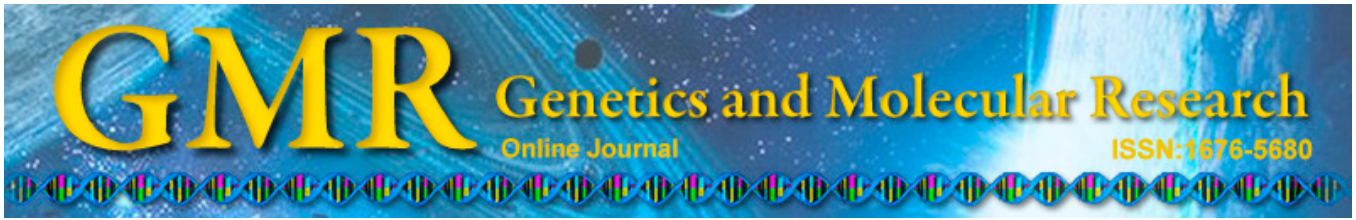

\title{
Genetic parameters for milk production traits and breeding goals for Gir dairy cattle in Brazil
}

\author{
M.A. Prata ${ }^{1}$, L.E. Faro ${ }^{2}$, H.L. Moreira ${ }^{1}$, R.S. Verneque ${ }^{3}$, \\ A.E. Vercesi Filho ${ }^{2}$, M.G.C.D. Peixoto ${ }^{3}$ and V.L. Cardoso ${ }^{1}$ \\ ${ }^{1}$ Departamento de Genética, Faculdade de Medicina de Ribeirão Preto, \\ Universidade de São Paulo, Ribeirão Preto, SP, Brasil \\ ${ }^{2}$ Instituto de Zootecnia, Secretaria de Agricultura e Abastecimento, \\ Centro Avançado de Pesquisa Tecnológica do Agronegócio de Bovinos de Corte, \\ Estação Experimental de Zootecnia, Sertãozinho, SP, Brasil \\ ${ }^{3}$ Embrapa Gado de Leite, Juiz de Fora, MG, Brasil \\ Corresponding author: M.A. Prata \\ E-mail:maprata@usp.br
}

Genet. Mol. Res. 14 (4): 12585-12594 (2015)

Received May 12, 2015

Accepted August 8, 2015

Published October 19, 2015

DOI http://dx.doi.org/10.4238/2015.October. 19.2

\begin{abstract}
To implement an animal breeding program, it is important to define the production circumstances of the animals of interest to determine which traits of economic interest will be selected for the breeding goal. The present study defined breeding goals and proposed selection indices for milk production and quality traits of Gir dairy cattle. First, a bioeconomic model was developed to calculate economic values. The genetic and phenotypic parameters were estimated based on records from 22,468 first-lactation Gir dairy cows and their crosses for which calving occurred between 1970 and 2011. Statistical analyses were carried out for the animal model, with multitrait analyses using the restricted maximum likelihood method. Two situations were created in the present study to define the breeding goals: 1) including only milk
\end{abstract}


yield in the breeding goal (HGL1) and 2) including fat and protein in addition to the milk yield (HGL2). The heritability estimates for milk, protein, and fat production were $0.33 \pm 0.02,0.26 \pm 0.02$, and $0.24 \pm$ 0.02 , respectively. All phenotypic and genetic correlations were highly positive. The economic values for milk, fat, and protein were US $\$ 0.18$, US $\$ 0.27$, and US\$7.04, respectively. The expected economic responses for HGL2 and for HGL1 were US\$126.30 and US\$79.82, respectively. These results indicate that milk component traits should be included in a selection index to rank animals evaluated in the National Gir Dairy Breeding Program developed in Brazil.

Key words: Gir dairy cattle; Genetic parameters; Breeding goal; Economic selection index

\section{INTRODUCTION}

The development of breeding programs involving Zebu cattle breeds in Brazil is necessary to ensure adequate maintenance of crossbreeding schemes that are widely used nationwide. Crossbred cattle (Zebu x European) are widely used in pasture-based milk production systems in Brazil because of their adaptation skills and account for roughly $80 \%$ of the milk produced in the country (Vercesi Filho et al., 2010).

To implement any animal breeding program, it is important to define the production circumstances of the animals of interest to determine which traits are of economic interest (breeding goals) and which will be measured (selection criteria). Hazel (1943) developed the selection index theory, which allows multiple-trait selection of animals, using economically important trait information or other measureable correlated traits that were directly obtained from individuals or their relatives and weighted by their economic values (EVs). Selection indexes have been implemented in several developed countries; consequently, dairy industries have considerably improved.

Initially, production traits were emphasized in these breeding programs (Wilmink, 1988; Harris, 1998). As information on traits related to health, fertility, and longevity started being recorded and genetically evaluated, they were gradually included in breeding goals for dairy cattle (VanRaden, 2004; Norman et al., 2010). Miglior et al. (2005) surveyed the selection indexes of 15 countries from different geographical regions and showed that the average relative emphasis for production across all countries was 59.5\%. This finding indicates that production is still the most important component of selection indexes used in dairy cattle.

Studies that involve economic selection indexes (ESIs) for dairy cattle have only been recently developed in Brazil and are still scarce for a variety of reasons, such as the diversity of production systems and slow implementation and diversity of payment policies for milk quality. Madalena (2000) simulated the expected response to selection indexes for milk, fat, and protein yields using EVs obtained for the prevailing payment policies in the States of Minas Gerais and Paraná. Expected responses were positive when using EVs obtained for payment circumstances in Paraná, where payment policies included bonuses for milk components. However, the expected responses were negative when using EVs obtained for the payment system in Minas Gerais, which was only based on milk volume. Seno et al. (2006) compared economic 
selection response for milk, fat, and protein yield for buffalo milk production systems, where two different payment policies for milk were applied. The first was based on the volume of milk sold to industry (MILK) and the second was based on the production of mozzarella cheese on the farm (MOZZARELLA). The authors found that the MOZZARELLA system had greater economic response to selection (US\$402.41) compared with the MILK system (US\$38.22). The authors attributed this difference to the fact that the EVs for the components of the milk were positive for the MOZZARELLA system, but negative for the MILK system.

After the implementation of Brazilian Agriculture Ministry regulation polices (Brasil, 2002), which established health and quality standards for raw and processed milk and milk products, some dairies started to adopt payment systems for milk based on quality by applying bonuses or penalties for fat and protein content and somatic cell count. The aim of this study was to obtain genetic parameters and EVs of milk production traits to estimate genetic and economic responses to different selection indexes for Gir dairy cattle, which is the main dairy Zebu breed in Brazil, by taking into account the production circumstances of crossbred commercial herds in Southeast Brazil.

\section{MATERIAL AND METHODS}

\section{Genetic parameters}

Genetic and phenotypic parameters were estimated based on productive performance data from the National Gir Dairy Breeding Program and carried out by the Brazilian Association of Gir Dairy Breeders (ABCGIL) in partnership with Embrapa Dairy Cattle. The data included milk production records from 22,468 first-lactation Gir dairy cattle and their crosses that experienced calving between 1970 and 2011.

The statistical analyses used to estimate genetic parameters for milk, fat, and protein production over a 305-day lactation period in an animal model were carried out using multitrait analyses. The model included the fixed effects of contemporary groups (herd and year at calving), calving season, cow's genetic composition, and age at calving as covariables (linear and quadratic effects). Direct additive genetic and temporary environmental effects were included as random effects. The variance components were estimated by the restricted maximum likelihood method using the WOMBAT software (Meyer, 2007).

\section{Production system description}

Productive and reproductive performance data were obtained between 2005 and 2008 from a rotational crossbred dairy herd involving Holstein $(\mathrm{H})$ and Gir $(\mathrm{G})$ cattle $(\mathrm{H} \mathrm{x} \mathrm{H} \mathrm{x} \mathrm{G})$ that were kept by Embrapa Dairy Cattle (Crossbred Milk Production System, CMPS) at an experimental farm located in Coronel Pacheco, MG, Brazil. These data were used to describe milk production system, which, based on production and market circumstances, represent an average milk commercial herd in Southeast Brazil.

The herd was maintained in a rotational pasture program. Lactating cows were managed exclusively fed with elephant grass (Pennisetum purpureum) during the rainy season (November-May) and received corn silage supplementation during the dry season (June-October), as well as concentrates ( $25 \%$ crude protein) throughout lactation in a concentrate:milk 
ratio of $1: 3$. In the dry season, $80 \%$ of consumed roughage came from corn silage, and the remaining $20 \%$ came from the pasture.

\section{EV calculation}

A bioeconomic model was developed using Excel to calculate productive performance as well as revenues and costs for milk, fat, and protein production traits and EVs based on biological and economic parameters (Tables 1 and 2). Fat and protein contents of milk were obtained from two herds located in São Paulo and Minas Gerais. Variable costs considered refer to all feeding components, and prices were obtained from CMPS cost worksheets and ANUALPEC (2011). Revenues from milk sales were calculated by including bonuses and penalties to the milk base price (US\$0.38) based on fat and protein contents. Information on class definition and bonus or penalty values were obtained from payment tables of two important industries in Southeast Brazil. To account for the differences between payment tables, all classes and respective additional values paid by the two companies were combined, and a linear regression analysis was used to determine the relationships between fat and protein contents and their associated EVs.

\begin{tabular}{|c|c|c|}
\hline Characteristics & Symbol & Means \\
\hline 305-day milk production $(\mathrm{kg})$ & P305 & 3278.42 \\
\hline Lactation length (days) & DLAC & 309.57 \\
\hline Daily milk production/cow $(\mathrm{kg})$ & DMPC & 10.46 \\
\hline Protein $(\%)^{1,2}$ & PRO & 3.26 \\
\hline Fat $(\%)^{1,2}$ & FAT & 3.71 \\
\hline Calving interval (days) & $\mathrm{CI}$ & 446.01 \\
\hline Cows in milk (\%) & $\% \mathrm{LC}$ & 69.41 \\
\hline Lactating cow weight $(\mathrm{kg})$ & LCW & 486.27 \\
\hline Dry cow weight $(\mathrm{kg})$ & DCW & 532.76 \\
\hline
\end{tabular}

Sources: ${ }^{1,2}$ Boa Sorte Farm, MG; ${ }^{1,2}$ Boa Esperança da Serra Farm, SP.

Table 2. Diet components and prices.
\begin{tabular}{lcccc}
\hline Components of the diet & DM $(\%)^{*}$ & TDN $(\%)^{*}$ & CP $(\%)^{*}$ & Price/kg DM (US\$) \\
\hline Corn silage & 30.00 & 64.00 & 7.26 & $0.10^{* *}$ \\
Elephant grass & 16.00 & 60.00 & 22.00 & $0.03 * *$ \\
Concentrate & 90.00 & 75.00 & $0.55^{* * *}$ \\
\hline
\end{tabular}

$\mathrm{DM}=$ dry matter; TDN $=$ total digestible nutrients; $\mathrm{CP}=$ crude protein. $*$ Valadares Filho (2006). ** ANUALPEC (2011). ***Embrapa Dairy Cattle (Crossbred Milk Production System - CMPS) (US\$1.00).

EVs were calculated as the marginal difference in profit from an increase of one unit of improvement compared with the original level of each trait while maintaining constant levels of the other traits. This approach maximizes profit and fixed herd size (Groen et al., 1997) as follows:

$$
\mathrm{EV}=[\delta(\text { annual revenue })-\delta(\text { annual cost })] \quad(\text { Equation } 1)
$$

where $\delta=$ marginal difference of annual revenues (or costs) that results from a one-unit increase of each trait due to genetic change, while the levels of the other traits remained constant. 


\section{Selection index}

Using the same production circumstances and prices, responses to selection for two alternative breeding goals were compared: 1) only milk production as the breeding goal, which is the most common practice in Brazil (HGL1) and 2) milk, fat, and protein yields as the breeding goal (HGL2).

Indexes were obtained based on the methodology described by Hazel (1943). Weighting factors $(b)$ were derived to maximize response in the aggregate genotype $(H)$ to the selection of individuals based on their index value $(I)$. Index weights were derived using the following matrix system equations:

$$
P b=G v
$$

(Equation 2)

where $P=$ is an $n \times n$ matrix of phenotypic variances and covariances among the $n$ traits measured; $b=$ weighting factor vector, maximizing the correlation between $H$ and $I ; G=$ is an $n \times m$ matrix of genetic variances and covariances among all $m$ traits in the breeding goal and those from the index; and $v=$ is an nxlvector of economic values of traits in the breeding goal.

Therefore, weighting factors were obtained by:

$$
b=P^{-1} G v
$$

The variances of index and breeding goal were obtained by:

$$
\left.\sigma_{I}^{2}=b\right\urcorner P b
$$

and

$$
\sigma_{H}^{2}=v^{`} \mathrm{C} v
$$

(Equation 5)

where $\sigma_{I}^{2}=$ index variance; $\sigma_{H}^{2}=$ breeding goal variance, and $C=$ is an $n \times n$ matrix of genetic covariance between the traits in the breeding goal.

Total expected selection response for each index $(R)$ was calculated by:

$$
R=i r_{I H} \sigma_{H}
$$

where $i=$ selection intensity; $\mathrm{r}_{I H}=$ correlation between breeding goal and selection index; and $\sigma_{H}=$ breeding goal standard deviation.

The correlation between the index and the breeding goal $\left(\mathrm{r}_{I H}\right)$ was calculated by $\sigma_{I} / \sigma_{H}$. The selection intensity was set to 1 .

The expected selection responses were expressed in US\$ (US\$1.00) and represents the average superiority, in monetary terms, of the progeny in the next generation. 


\section{RESULTS}

\section{Genetic parameters}

The average milk, fat, and protein productions and standard deviations were 2,965.33 $\pm 1,558.46,112.38 \pm 58.40$, and $90.14 \pm 48.81 \mathrm{~kg}$, respectively. The estimates for genetic and phenotypic correlations for first-lactation milk, fat, and protein yields are described in Table 3. There was a high genetic correlation among the traits, indicating that direct selection for increased milk production would also lead to increased fat and protein production. The heritability estimates for milk yield, fat, and protein yields were $0.33 \pm 0.02,0.24 \pm 0.02$, and 0.26 \pm 0.02 , respectively.

Table 3. Estimates of genetic (above the diagonal) and phenotypic correlations (below the diagonal) for 305day milk production $(\mathrm{kg})$, fat $(\mathrm{kg})$, and protein $(\mathrm{kg})$ for first lactation Gir dairy cows.

\begin{tabular}{lccc}
\hline Trait & Milk $(\mathrm{kg})$ & Fat $(\mathrm{kg})$ & Protein $(\mathrm{kg})$ \\
\hline Milk & - & $0.92 \pm 0.01$ & $0.97 \pm 0.01$ \\
Fat & $0.88 \pm 0.00$ & - & $0.95 \pm 0.01$ \\
Protein & $0.91 \pm 0.00$ & $0.92 \pm 0.00$ & - \\
\hline
\end{tabular}

\section{EVs and selection indexes}

Figures 1 and 2 show the additional payment values estimated for fat and protein production by regression equations. $R^{2}$ coefficients were 0.96 for fat and 0.93 for protein. These values were close to zero when fat and protein contents were close to the minimum values established by the government ( 3.0 and 2.9 for fat and protein content, respectively).

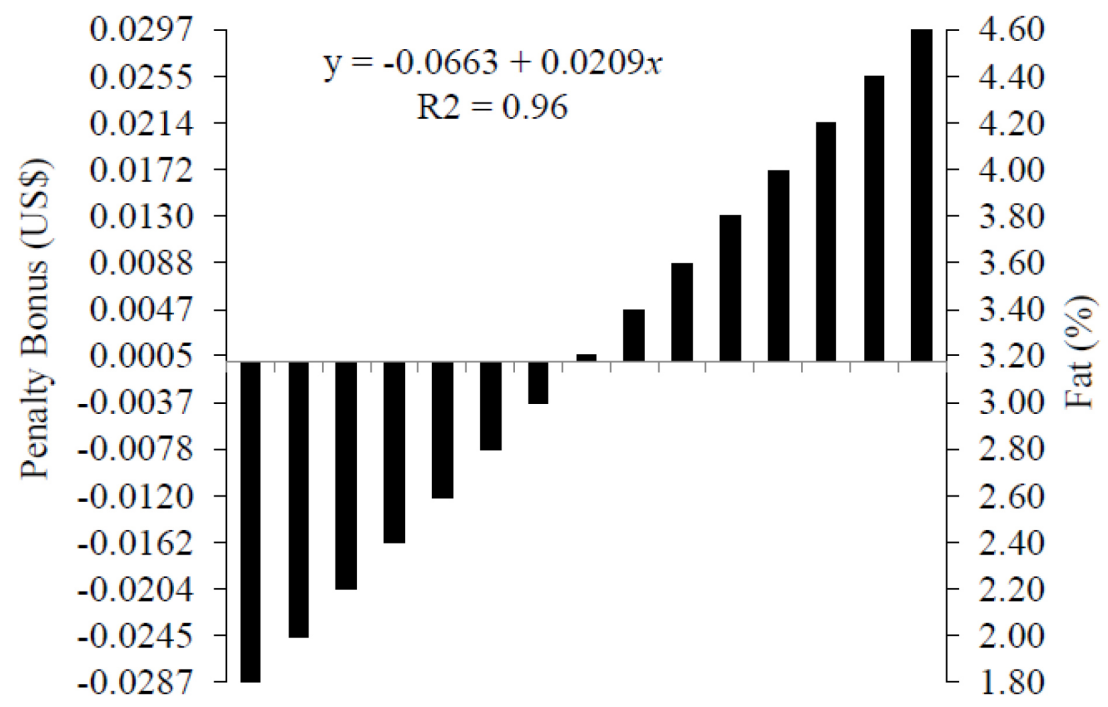

Figure 1. Regression analysis of the average class intervals on the additional payment values across the two milk companies for fat content (US\$1.00). 


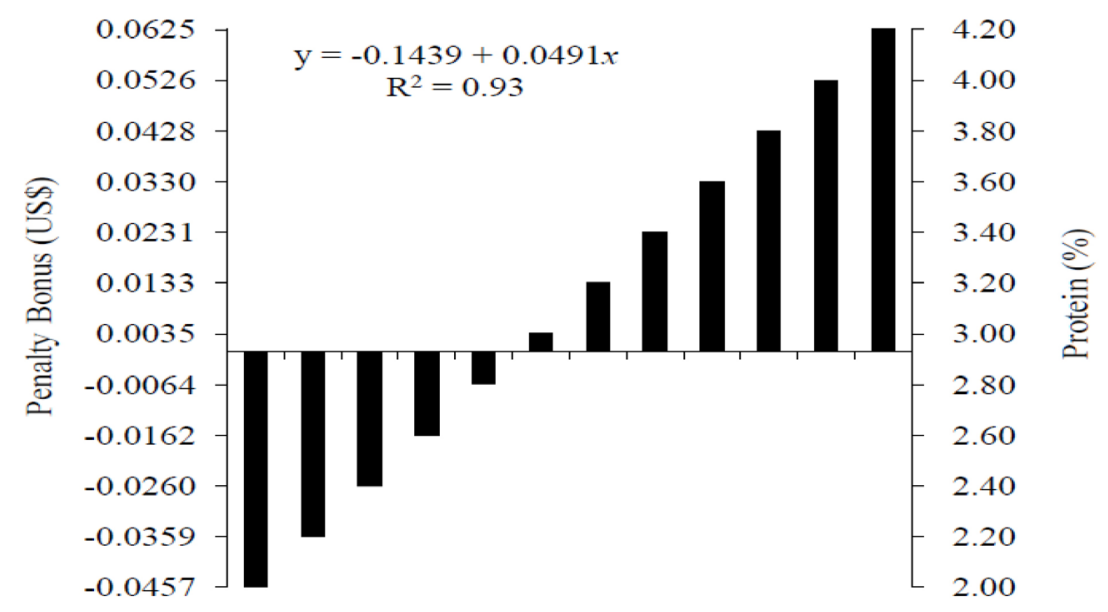

Figure 2. Regression analysis of the average class intervals on the additional payment values across the two milk companies for protein content (US\$1.00).

The EVs for milk, fat, and protein yields were US\$0.18, US\$0.27, and US\$7.04, respectively. The EVs are consistent with the global trend of being associated with increased protein content.

The expected genetic gains for milk production in the HGL1 and HGL2 indexes (Table 4) were similar. However, there was a notable difference in genetic gains for fat and protein production. Because the breeding goal in HGL2 included the solid components of milk (fat and protein), the genetic gains for these two traits were approximately 3.4 times greater than for those in HGL1.

Table 4. Weighting factors $\left(b_{i}\right)$, expected genetic gain for the different traits, overall expected economic response $(R)$, and correlation between the index and breeding goal $\left(\mathrm{r}_{\mathrm{IH}}\right)$ of the selection indexes.

\begin{tabular}{|c|c|c|c|c|c|c|c|c|}
\hline \multirow[t]{2}{*}{ Index } & \multicolumn{3}{|c|}{ Weighting factors $\left(b_{i}\right)$} & \multicolumn{3}{|c|}{ Expected genetic gain ${ }^{1}$} & \multirow[t]{2}{*}{$R$ (US\$) } & \multirow[t]{2}{*}{$\mathrm{r}_{I H}$} \\
\hline & Milk & Fat & Protein & Milk (kg) & Fat $(\mathrm{kg})$ & Protein $(\mathrm{kg})$ & & \\
\hline $\begin{array}{l}\text { HGL1 } \\
\text { HGL2 }\end{array}$ & $\begin{array}{l}0.08 \\
0.15\end{array}$ & $\begin{array}{l}-0.64 \\
-1.16\end{array}$ & $\begin{array}{l}0.03 \\
0.54\end{array}$ & $\begin{array}{l}338.58 \\
337.74\end{array}$ & $\begin{array}{r}2.92 \\
10.14\end{array}$ & $\begin{array}{l}2.60 \\
8.93\end{array}$ & $\begin{array}{r}79.82 \\
126.30\end{array}$ & $\begin{array}{l}0.59 \\
0.57\end{array}$ \\
\hline
\end{tabular}

${ }^{1}$ Genetic gain calculated assuming selection intensity of 1 and the same generation interval for every trait (US\$1.00).

ESIs select traits for animal breeding programs based on economic importance. To compare the expected efficiency of selection based on different indexes, an assessment of the expected economic response to selection $(R)$ was carried out to compare the two proposed breeding goals. $R$ for HGL1 and for HGL2 were US\$79.82 and US\$126.30, respectively (Table 4).

\section{DISCUSSION}

Genetic parameters were estimated to calculate the selection indexes and were similar 
to those obtained in other studies in Brazil (Herrera et al., 2008; Verneque et al., 2013). The EVs calculated for protein and fat production were positive, which indicates that increasing their production through selection would increase profit. That is, selection for these traits, and especially for increased protein production, would provide an advantageous economic gain for the producer. This tendency has been observed in several countries where this economic value of protein production is greater, less for fat, and even negative for milk volume (Dekkers, 1991; Veerkamp et al., 2002; Gonzáles-Recio et al., 2004; Wolfová et al., 2007; Amer et al., 2013).

The expected genetic gains for milk yield, $338.58 \mathrm{~kg}$ for HGL1 and $337.74 \mathrm{~kg}$ for HGL2 per generation, were greater than the $206 \mathrm{~kg}$ reported by Herrera et al. (2008) for Gir dairy cattle. This disparity in findings may be related to the greater estimate of additive genetic variation for this trait in this study. The expected genetic gains for fat and protein yields were higher for HGL2 than HGL1, because there was direct selection for milk components in HGL2.

Dairy cattle selection in Brazil has primarily centered on milk production for decades. However, the results from the present study show that an ESI that includes fat and protein would increase the economic genetic efficiency of herds in this country by taking into account the current production components and milk payment policies. When fat and protein were also included in the breeding goal (HGL2), the expected economic response to selection was $37.33 \%$ greater (US\$127.37) compared with the response for HGL1 (US\$79.82). It is difficult to compare these results with those of similar studies in Brazil, because milk payment policies are quite recent in the country. In the simulation study developed by Madalena (2000), who calculated EVs for Paraná where a bonus policy for milk components was applied, a positive selection response was obtained for an index that included milk volume and components.

There is a seemingly irreversible trend in the dairy industry toward providing bonuses for milk components (fat and protein) and not based on milk price by volume alone. This trend will also continue in the coming years because of the implementation of Normative Instruction 51 (NI 51) by the Ministry of Agriculture, Livestock and Supply (Brasil, 2002). This document established the minimum standards of milk quality, in terms of composition and health, to be achieved by farmers to improve the milk quality produced in this country. As determined in this study, these changes and, consequently, the larger bonuses for milk components (as shown in Figures 1 and 2) resulted in positive EVs and favorable weightings in the selection indexes for these traits. Thus, it would be economically interesting for producers to increase milk components, especially protein and fat, by using bulls with positive genetic values for these traits or desirable ESI values.

Other traits related to health, fertility, conformation, and other relevant functional traits could be also included in breeding objectives for dairy breeding programs in Brazil, which is already widely used in several developed countries (Miglior et al., 2005). However, data recording systems in the country are still insufficient. As data on these traits become available, new studies will be possible by adding new traits to selection indexes for evaluation and comparison of selection responses.

Selection for milk, fat, and protein yields could increase the economic genetic efficiency of herds by taking into account the current production components and milk payment policies. The achieved results indicate that it is feasible and economically desirable to include protein and fat yields in addition to milk yield in breeding goals for Gir dairy cattle selection programs in Brazil. 


\section{Conflicts of interest}

The authors declare no conflict of interest.

\section{ACKNOWLEDGMENTS}

The authors thank Coordenação de Aperfeiçoamento de Pessoal de Nível Superior (CAPES), Conselho Nacional de Desenvolvimento Científico e Tecnológico (CNPq) and Fundação de Amparo à Pesquisa do Estado de Minas Gerais (FAPEMIG) for financial support and the Brazilian Association of Gir Dairy Breeders (ABCGIL) and Embrapa Gado de Leite for making the data available for conducting the present study.

\section{REFERENCES}

Amer PR, Santos B, Byrne TJ, Ludemann C, et al. (2013). An update of the national breeding objective for the New Zealand dairy industry. Int. Bull. 47: 23-25.

ANUALPEC (2011). Anuário da Pecuária Brasileira. FNP Consultoria e Comércio, São Paulo.

Brasil (2002). Ministério da Agricultura, Pecuária e Abastecimento. Instrução Normativa no 51 de 18/09/2002. Diário Oficial da União de 20/09/2002 - Brasil, Seção 1, 13. Available at [http://www.jusbrasil.com.br/diarios/709058/pg13-secao-1-diario-oficial-da-uniao-dou-de-20-09-2002].

Dekkers JCM (1991). Estimation of economic values for dairy cattle breeding goals: bias due to sub-optimal management policies. Livest. Prod. Sci. 29: 131-149.

González-Recio O, Pérez-Cabal MA and Alenda R (2004). Economic value of female fertility and its relationship with profit in Spanish dairy cattle. J. Dairy Sci. 87: 3053-3061.

Groen AF, Steine T, Colleau JJ, Pedersen J, et al. (1997). Economic values in dairy cattle breeding, with special reference to functional traits. Report of an EAAP - working group. Livest. Prod. Sci. 49: 1-21.

Harris DL (1998). Livestock improvement: art, science, or industry? J. Anim. Sci. 76: 2294-2302.

Hazel LN (1943). The genetic basis for constructing genetic indexes. Genetics 28: 476-490.

Herrera LGB, El Faro L, Albuquerque LG, Tonhati H, et al. (2008). Parâmetros genéticos para produção de leite no dia do controle e para produção de leite até 305 dias nas primeiras lactações de vacas da raça Gir. Rev. Bras. Zootec. 37: 17741780. Available at [http://www.scielo.br/readcube/epdf.php?doi=10.1590/S1516-35982008000900009\&pid=S151635982008000900009\&pdf_path=rbz/v37n9/a09v 37n9.pdf].

Madalena FE (2000). Consequências econômicas da seleção para gordura e proteína do leite. Rev. Bras. Zootec. 29: 685691. Available at [http://www.scielo.br/readcube/epdf.php?doi=10.1590/S1516-359820000 00300007\&pid=S151635982000000300007\&pdf_path=rbz/v29n3/5810.pdf].

Meyer K (2007). WOMBAT: A tool for mixed model analyses in quantitative genetics by restricted maximum likelihood (REML). J. Zhejiang Univ. Sci. 11: 815-821.

Miglior F, Muir BL and Van Doormaal BJ (2005). Selection indices in Holstein cattle of various countries. J. Dairy Sci. 88: $1255-1263$

Norman HD, Wright JR and Miller RH (2010). Response to alternative genetic-economic indices for Holsteins across 2 generations. J. Dairy Sci. 93: 2695-2702.

Seno LO, Cardoso VL and Tonhati H (2006). Responses to selection for milk traits in dairy buffaloes. Genet. Mol. Res. 5: 790-796.

Valadares Filho SC, Marcondes MI, Chizzotti ML and Paulino PVR (2006). Tabelas brasileiras de composição de alimentos para bovinos. 2nd edn. Editora da Universidade Federal de Viçosa, Viçosa.

VanRaden PM (2004). Invited review: selection on net merit to improve lifetime profit. J. Dairy Sci. 87: 3125-3131.

Veerkamp RF, Dillon P, Kelly E, Cromie, et al. (2002). Dairy cattle breeding objectives combining yield, survival and calving interval for pasture-based systems in Ireland under different milk quota scenarios. Livest. Prod. Sci. 76: $137-151$.

Vercesi Filho AE, Verneque RS, Peixoto MGCD, Machado MA, et al. (2010). Selection of tropical Dairy Cattle - The Experience from the Brazilian Gyr and Guzerat. Proceedings of the 9th World Congress of Genetics Applied to Livestock Production, Leipzig.

Verneque RS, Panetto JC, Peixoto MGCD, Bruneli FAT, et al. (2013). Programa Nacional de Melhoramento do Gir 
Leiteiro, Sumário Brasileiro de Touros - Resultado do Teste de Progênie, 4a Prova de Pré-Seleção de Touros. Embrapa Gado de Leite (Documentos 162), Juiz de Fora.

Wilmink JBM (1988). Selection on fat and protein to maximise profit in dairy herds. Livest. Prod. Sci. 20: 299-316.

Wolfová MJ, Wolf J, Kavapilík J and Kica J (2007). Selection for profit in cattle: economic weights for purebred dairy cattle in Czech Republic. J. Dairy Sci. 90: 2442-2455. 